\title{
ANALYSIS OF FEMALE HEPTATHLON IN IAAF WORLD ATHLETIC CHAMPIONSHIPS U18
}

\author{
Iva Dimova
}

National Sports Academy "Vassil Levski", Sofia, Bulgaria

\begin{abstract}
Women's heptathlon is an athletic discipline which in recent years have gained more interest. The athletes participating also called all-rounders are equally good in the technique of most of the seven disciplines. There is less information about female types of all-rounders, compared to male. That is why our interest lead us to investigate world elite for the age group under 18 years, who may be the future top athletes at senior age.

As database we use the results from IAAF World Championships in the studied age. In the current study are used variance analysis, correlation and sigmal method for assessment scale. From the results we determine the evolution of sport performance in combined events. We introduce criteria for estimating the type of female athletes in heptathlon, according to the gathered points. We analyze competitors which finished all seven disciplines

The best sport result through the years varies from 3310 points to 6037 points. The mean results for the groups in the different years is also shown and its dynamic shows ascending tendency for the girls U18, according to the overall points. From 2005 to 2017 the points gradually increased from 4762 to 5313. These results show that the discipline is still developing with positive pace. Some of the individual results are closer to senior results. Level of correlation between the score in separate events in heptathlon and the final score is highly dependable on events from the group of sprint athletic disciplines.
\end{abstract}

Key words: heptathlon, tendency, performance, female, assessment

\section{INTRODUCTION}

In recent years heptathlon is one of the most fascinating disciplines gaining more and more interest among the public. New formats of competitions only for combined events have appeared. This discipline offers an incomparable show and the athletes participating in such discipline are the most complex athletes. They are capable of achieving good results not only in one discipline, but in seven.

We are interested in the sport result of the junior athletes under 18 years which are on the edge of high-performance level. Studying the sport results in this age group can reveal what is needed to be distinguished among other athletes.

Many authors agree that in combined events bio-motor developments, expressed in different forms is highly desirable in athletes (P.Jev rábek, 2003; J. Vindusková, 2003; B. Mackenzie, 2000; Gutev, Njagin, 2012) Some of the disciplines within the combined events may be more suited than others to the abilities of a talented athlete. The training strategy and content must take this into account.

For an athlete who was selected to compete in combined events it is necessary to start preparation for separate disciplines and learn proper technique at the age of 10-13 years (Dimitrov, et al.,1986; Kadijski, 1980). The whole process is long, and it has to be subordinate to specific characteristic of the age group. When athletes are younger, they tend to have big jumps in their best sport result and as they grow older the performance gradually stabilizes. Sometimes we can happen upon athletes who have good results and then followed by a drop of the results. This is normal during the development stages of an athlete, especially combined events, because the training process is far more difficult (Dimitrov, et al., 1986; Kadijski, 1980; Vindušková et al., 2002).

We think that heptathlon for girls under 18 years of age is fascinating and undoubtedly studying sport result in different disciplines can reveal significant trends in young athletes' development. A study of Gr. Gutev deals with the relation between score in separate disciplines and the overall result (Gutev, 2013; Gutev, Njagin, 2012). A part of our study also refers to the approach used in Gutev's study. To look deeper into the careers and difference in performance of under 18 years girls is interesting, because some of the athletes at the studied group show potential to be future champions at senior level. 
Aim and Objectives of the Study

The aim study is to analyze the sport result in heptathlon for girls under 18 years, who are part of world elite.

Our aim led us to reveal the following steps:

Gather results from the studied period and composing database and comparative analysis.

Establishing any tendencies for the studied age group.

Deliver an assessment criterion for sport results in heptathlon for girls under 18 years.

\section{RESULTS}

When participating in World athletic forums only the best athletes gather to compete, because most of them had to obtain a qualifying norm to participate in this event. Figure № 1 shows the number of participants during the studied period. We observe undulant pattern on the graphic variating between 12 and 35 participants. Less than 15 athletes are not a big number. For instance, it is only 2 heats of a sprint events. Luckily only in two occasions the
Object of the study are female athletes from IAAF World Championship from 2005 to 2017.

Subject of the study is the sport results in points, according to the score tables of IAAF.

\section{METHODS}

For the purpose of the study we used results from the period 2005-2017, which included 6 World Athletic Championships. We included only results of competitors who have finished all seven events in the competition and did not score 0 points in any discipline. We used variance analysis, correlation and sigmal method. All results are official presented by the site of the International Association of Athletic Federations.

competitors are equal or less than 15, in 2009 and in 2017 . The $4^{\text {th }}$ and the $9^{\text {th }}$ IAAF world championships in Marrakech and Cali were with highest rates of rivalry. In Marrakech there were 35 heptathlon athletes who finished the event and in Cali were 34. At the other forums the number is around 30 athletes. However, the low number in 2017 is surprising and low number can mean a withdraw from heptathlon.

\section{Number of participants during IAAF competitions}

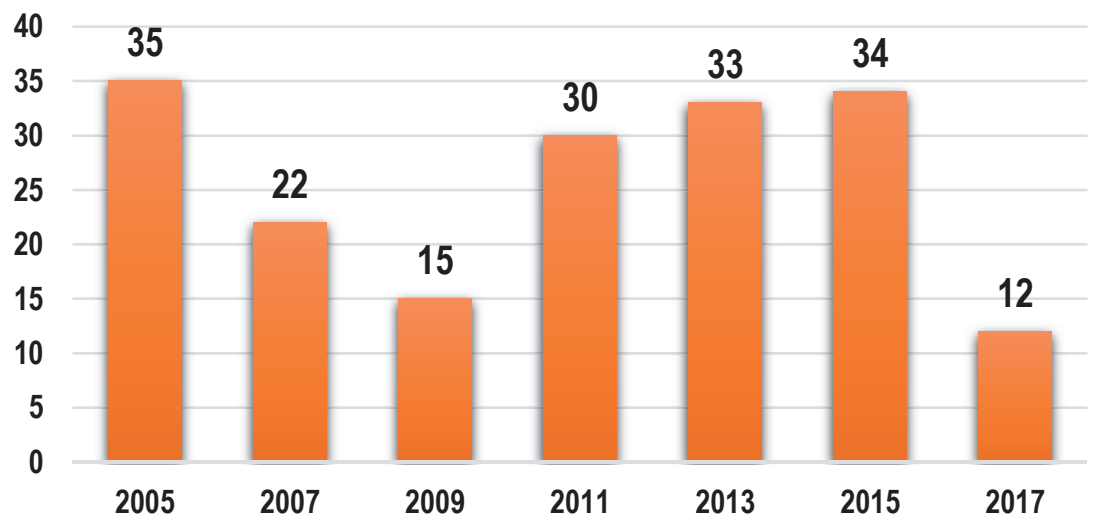

Figure 1. Number of female heptathlon athletes in IAAF World Championships.

The graphic on figure 2 shows average results through the years and the trend which the results draw. According to the data the lowest average result is in Marrakech, 2005 (4762 points), which can be explained also with the lowest number of participants. Next IAAF championships indicate slight ascent of the results and the line of 5000 points is crossed. In Cali, 2015 where we note the highest number of athletes, is also the year with the highest average score (5313 points). We can conclude that the bigger the number of competitors the higher the score is. 
From 2005 to 2017 the points gradually increased cipline is still developing with positive pace. Some from 4762 to 5313 . These results show that the dis- of the individual results are closer to senior results.

\section{Average result}

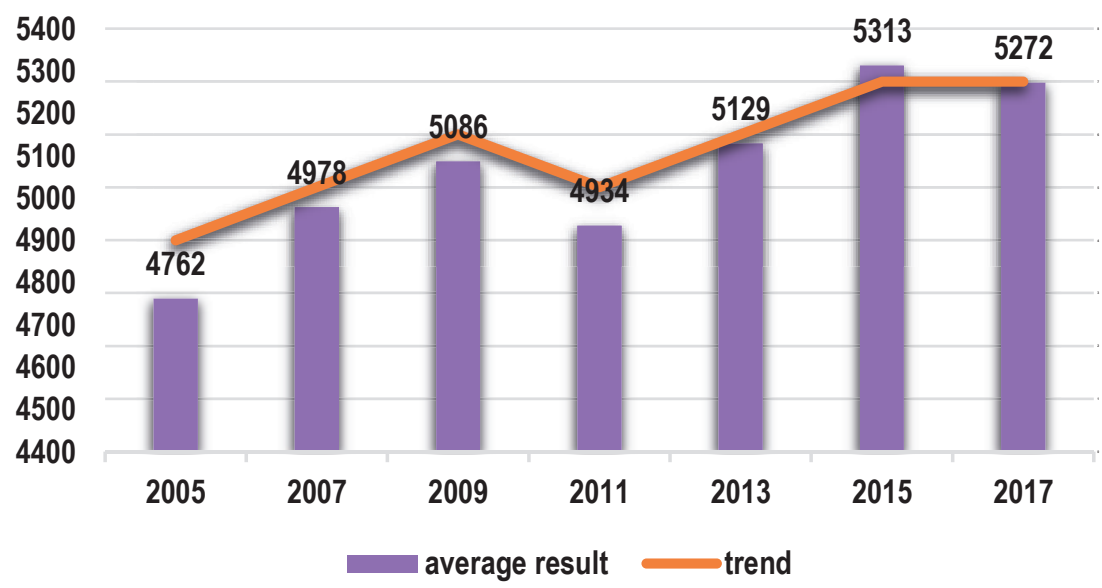

Figure 2. Average result during the analyzed period

Table 1 shows the results from variance analysis. disciplines. In the other disciplines the values are The number of all studied cases is 181 . From the over 100 points and also the coefficient of variance analysis we can clearly point that the most highly show that the groups are not so homogeneous.

awarded discipline is $100 \mathrm{~m}$ hurdles with over 890 points. The second-best discipline according to the group is $200 \mathrm{~m}$ (793 points). Athletes tend to show good results in the sprint events, and we can also see that they are awarded more points in jumps rather than throws and middle distance run. This can be explained by the fact that speed abilities affect more jumping events, because speed is necessary prerequisite and a sport factor for good performance.

The athletes' results are most homogenous in $100 \mathrm{~m}$ hurdles $(\mathrm{V} \%=9,49)$ and $200 \mathrm{~m}(\mathrm{~V} \%=10,30)$, which is also supported by the values of the standard de-

The average result for the whole period is 5048 points, but the range between the best and the lowest results is over 2900 points which in heptathlon is very great difference, given the fact that we only included heptathletes who finished all separate events. Standard deviation is 441 points and according to $\mathrm{V} \%$ the degree of variance in the group is $8,74 \%$. This means that the group is highly homogenous. Coefficient of asymmetry (As) is with negative sign above the critical value, which means that the results of the athletes are drawn more to the 5000-point mark than in 6000 points. viation which is under 100 points only in these two

Table 1.Variance analysis of results from IAAF World Athletic Championships under 18 years

\begin{tabular}{|c|c|c|c|c|c|c|c|c|c|}
\hline & $\mathbf{n}$ & $\mathbf{X} \mathbf{m i n}$ & $\mathbf{X} \mathbf{m a x}$ & $\mathbf{R}$ & $\mathbf{X}$ & $\mathbf{S}$ & $\mathbf{V}$ & $\mathbf{A s}$ & $\mathbf{E x}$ \\
\hline $\mathbf{1 0 0} \mathbf{m} \mathbf{H}$ & 181 & 430 & 1060 & 630 & 895 & 85 & 9,49 & $-1,127 *$ & $4,107 *$ \\
\hline $\mathbf{H J}$ & 181 & 566 & 1029 & 463 & 793 & 101 & 12,76 & $-0,047$ & $-0,423$ \\
\hline $\mathbf{S P}$ & 181 & 344 & 904 & 560 & 606 & 104 & 17,13 & 0,267 & 0,001 \\
\hline $\mathbf{2 0 0} \mathbf{~ m}$ & 181 & 406 & 981 & 575 & 798 & 82 & 10,30 & $-0,654^{*}$ & $1,958^{*}$ \\
\hline $\mathbf{L J}$ & 181 & 91 & 946 & 855 & 695 & 109 & 15,68 & $-1,175^{*}$ & $4,839 *$ \\
\hline $\mathbf{J T}$ & 181 & 250 & 946 & 696 & 571 & 126 & 22,04 & 0,038 & 0,036 \\
\hline $\mathbf{8 0 0} \mathbf{m}$ & 181 & 360 & 912 & 552 & 703 & 102 & 14,49 & $-0,535^{*}$ & 0,352 \\
\hline & 181 & 3103 & 6037 & 2934 & 5048 & 441 & 8,74 & $-0,519^{*}$ & $1,179 *$ \\
\hline
\end{tabular}

Data from correlation analyses is shown on table awarded points in $200 \mathrm{~m}$ are significantly depen№ 2. As to the results between separate events the dent with the points awarded in $100 \mathrm{~m}$ hurdles 
$(\mathrm{r}=0,666)$. This is explicable by the fact that these two disciplines are classified in sprint group in athletics and a good result in $100 \mathrm{~m}$ hurdles leads to good results in $200 \mathrm{~m}$. It can also be referred to the fact that preparation is led properly, and the athletes managed to reach good speed and speed endurance in the competition. Speed qualities in 100 $\mathrm{m}$ hurdles and $200 \mathrm{~m}$ also correlate significantly with long jump ( $\mathrm{r}=0,524, \mathrm{r}=0,542)$. Speed qualities are also important for high jump but the correlation between $100 \mathrm{~m}$ hurdles or $200 \mathrm{~m}$ and high jump is slightly over 0,300 . This means that the correlation is moderate. We can explain the moderate correlation with the fact that high jump is technically difficult discipline and the young female athletes can find it hard to put on the gained speed during the approach.

The final score strongly correlates with the result of $100 \mathrm{~m}$ hurdles $(\mathrm{r}=0,703)$. Relation between the final score and the score in $200 \mathrm{~m}$ is significant $(\mathrm{r}=0,682)$. These results show us once again that athletes tend to show more speed qualities and the overall score is more dependable to sprint and jumping events. The performance in middle distance run $(800 \mathrm{~m})$ has the smallest impact on the final score $(\mathrm{r}=455)$, but still has a moderate correlation. Actually, the presented data shows that to be successful in heptathlon speed qualities are important.

Table 2. Correlation analyses in heptathlon in IAAF World Athletic Championships

\begin{tabular}{|c|c|c|c|c|c|c|c|c|}
\hline & $100 \mathrm{~m} \mathrm{H}$ & HJ & SP & $200 \mathrm{~m}$ & $U$ & JT & $800 \mathrm{~m}$ & RESULT \\
\hline $100 \mathrm{~m} \mathrm{H}$ & 1 & & & & & & & \\
\hline HJ & 0,308 & 1 & & & & & & \\
\hline SP & 0,285 & 0,190 & 1 & & & & & \\
\hline $200 \mathrm{~m}$ & 0,666 & 0,304 & 0,178 & 1 & & & & \\
\hline$U$ & 0,524 & 0,455 & 0,275 & 0,542 & 1 & & & \\
\hline $\mathrm{JT}$ & 0,196 & 0,134 & 0,403 & 0,133 & 0,141 & 1 & & \\
\hline $800 \mathrm{~m}$ & 0,334 & 0,162 & 0,109 & 0,262 & 0,134 & 0,086 & 1 & \\
\hline RESULT & 0,703 & 0,593 & 0,568 & 0,621 & 0,682 & 0,521 & 0,455 & 1 \\
\hline
\end{tabular}

In Table 3 we present an assessment table for the sport result of the heptathlon athletes and their coaches. It is easily applicable in practice. Using the scale, we can make conclusions about the quality of the results reached in the different championships. According to our scale only at the last two championships the results can be defined as above average. As to individual results in each different championship between 2 and 5 athletes have sport results defined as high. We can note that the quality of results in 2015 is the highest according to our assessment scale, and also there is the first break of 6000 points in this age group in the studied period. And a result over 6000 points can be classified as very high result.

Table 3. Criteria for assessing the sport result for the World elite for girls under 18 years

\begin{tabular}{|c|c|}
\hline ASSESSMENT & POINTS \\
\hline very high & above 5930 \\
\hline high & from $\mathbf{5 4 9 0}$ to $\mathbf{5 9 3 0}$ \\
\hline above average & from $\mathbf{5 2 7 0}$ to $\mathbf{5 4 8 9}$ \\
\hline average & from $\mathbf{4 8 2 9}$ to 5296 \\
\hline below average & from 4608 to 4828 \\
\hline low & from 4166 to 4607 \\
\hline very low & under 4166 \\
\hline
\end{tabular}




\section{DISCUSSIONS}

1. Positive dynamic is revealed, regarding to the improvement of sport results in combined events in recent years in the studied age group. The discipline is still developing, and we expect more improvements of the sport result. We observe results closer to senior level.

2. The most awarded disciplines with points are 100 $\mathrm{m}$ with hurdles and $200 \mathrm{~m}$, both in sprint event groups. In second place are jumping events, which is explicable by the relations between speed and jump events.

3. Level of correlation between the score in separate events in heptathlon and the final score is highly dependable on events from the group of sprint athletic disciplines.

\section{REFERENCES}

Bulgarian athletic federation. (2019). Systezatelni pravila IAAF 2018 - 2019 g. https://www.bfla.org/, (accessed July 25 2019).

Decathlon 2000. (2019). Decathlon 2000 web site. https://www.decathlon2000.com/ (accessed August 10 2019).

Dimitrov. D., Stoqnova, V., Aladjov, K. (1986). Edinna programa po leka atletika za obuchenie i trenirovka $\mathrm{V}$ shkolite za masov sport i sportnite sektsii na KFTS i SFS, ETSNPKFKS. Sofiya.

Gutev, Gr. (2013). Zavisimosti i dinamika mezhdu rezultatite $\mathrm{v}$ otdelnite distsiplini i krainnoto postizhenie $\mathrm{v}$ chetiriboya za momicheta pod 14 god. Sbornik dokladi ot Mezhdunarodna nauchna konferentsiya "Evropeuski standarti v sportnoto obrazovanie", Vratsa.

Gutev, Gr., Njagin, Nj. (2012). Research on the Bulgarian U14 track and field status and tendency of de- velopment. Book of abstracts International Scientific Conference "Effects of Physical Activity Application to Anthropological Status of Children, Youth and Adults", Faculty of Sport and Physical Education, Beograde, Serbia 11-12 december. ISSN978-86-82055-92-7;2,6, pp. 183.

IAAF. (2019). IAAF official web page. https://www. iaaf.org/ (accessed August 10 2019).

Je rábek, P. (2003). The preparation of junior athletes for the combined events. NSA 18:4; pp. 37-43.

Kadijski. I. (1980). Fizicheska podgotovka na mladite lekoatleti-mnogoboĭtsi, Trenjorska misal, N 11, V. Naroden Sport, pp. 40-46.

Siris, P., Gajdarska, P., Rachev, K. (1983). Otbor i prognozirovaniye spotsobnostey $\mathrm{v}$ legkoy atletike. Moska „Fizkultura i sport”, pp. 73-92.

Vindusková J. (2003). Training women for the Heptathlon - A brief outline. IAAF, 18:2; pp. 27-24.

Vindušková, J. Vindušková, J. (2002). Technical Technical Aspects Aspects in Combined Combined Events [Aspekt [Aspekty techniky ve vícebojích y techniky ve vícebojích]. In Technique Technique in Athletics Athletics [Technika v atletice]. E.A.C.A. Congress. Catez 15 -17 November.

Westera, W. (2006). Under attack: the heptathlon scoring method. Open University of the Netherlands, http:// hdl.handle.net/1820/2089 (accessed July 26 2019).

Corresponding author:

Iva Dimova, $\mathrm{PhD}$

National Sports Academy "Vassil Levski", Department “Track \& Field”Bulgaria, Studentski grad, Sofia, postal code 1700

E-mail: ivi4et_0@abv.bg 